\title{
The Impact of Air Pollution on Human Health in Suwon City
}

\author{
Sang Jin Jeong* \\ Department of Environmental Energy Engineering, Kyonggi University, Suwon, Gyeonggi-do 442-760, Korea \\ *Corresponding author. Tel: +82-31-249-9734, E-mail: sjjung@kyonggi.ac.kr
}

\begin{abstract}
Scientific evidence shows that ambient air quality is one of the major environmental issues related to human health. The aim of this paper was to provide quantitative data on the short-term impact of air pollution on the mortality and morbidity of people living in Suwon city. There are some studies that have conducted health impacts of the air pollution in Seoul, Korea. However, there are few studies of the health effects on air pollution conducted in satellite cities of the Seoul Metropolitan area. For this reason, we investigated the health effects of air pollution in Suwon city, one of the highly populated satellite cities of Seoul. In order to estimate the short-term mortality impact of air pollution, this study applied the approach suggested by the World Health Organization (WHO), using AirQ2.2.3 software. Daily concentrations of $\mathrm{PM}_{10}, \mathrm{O}_{3}, \mathrm{NO}_{2}$, and $\mathrm{SO}_{2}$ were used to assess human exposure and health effects, in terms of attributable proportion of the health outcome, annual number of excess cases of mortality for all causes, and cardiovascular and respiratory diseases. Among the four considered air pollutants, $\mathrm{PM}_{10}$ had the highest health impact on the $1,118,000$ inhabitants of Suwon city, causing an excess of total mortality of 105 out of 4,254 in a year. Sulfur dioxide had the least health impact. Ozone and nitrogen dioxide each caused 42.7 and 81.3 excess cases of total mortality in a year. The results are also in line with those of other international studies that apply AirQ software.
\end{abstract}

Key words: Ambient air pollution, Health impact, Mortality, AirQ software, Suwon city

\section{INTRODUCTION}

Air pollution levels in many Asian cities, including Korea, remain well above WHO guideline values. In Korea, the annual mean $\mathrm{PM}_{10}$ should not exceed 50 $\mu \mathrm{g} / \mathrm{m}^{3}$ (limit values set in 2005), and it is requested to reduce $\mathrm{PM}_{2.5}$ exposure in urban areas below $25 \mu \mathrm{g} / \mathrm{m}^{3}$ by 2015 (legally binding value). These values still offer exposure to concentrations exceeding the WHO recommendations.

Many researchers have studied the impact of air pollution on human health, and have demonstrated links between air pollution and mortality (HEI, 2010; Pope and Dockery, 2006). According to a World Health Organization (WHO, 2006) assessment of the burden of disease due to air pollution, more than two million premature deaths each year can be attributed to the effects of urban outdoor air pollution and indoor air pollution. WHO estimated that urban particulate air pollution contributed to approximately 800,000 deaths and 6.4 million lost life years worldwide in 2000, with two-thirds of these losses occurring in Asia (Atkinson et al., 2012). Several epidemiological studies also have reported associations between an increase in daily levels of ozone and particulate matter, and an increase of the mortality and hospital admissions predominantly related to respiratory and cardiovascular diseases (Pacel et al., 2013).

There are some studies that have conducted health impacts of the air pollution in Seoul, Korea (Lee et al., 2011; Yi et al., 2010; Bae and Park, 2009; Lee et al., 2007; Kim et al., 2004). Kim et al. (2004) studied the threshold effect of ozone on daily mortality in Seoul. Lee et al. (2007) investigated the relative risk of mortality associated with Asian dust events in Seoul. Bae and Park (2009) investigated the short-term association between air pollution and mortality, and assessed the impact of improved air quality on mortality in a rapidly aging city, Seoul. Yi et al. (2010) examined the associations between $\mathrm{PM}_{10}$ concentrations, mortality and hospital admissions in Seoul for the periods 2000-2006 and 2001-2006. Lee et al. (2011) performed a health risk assessment based on an exposure response function, and evaluated the prospective damage costs of $\mathrm{PM}_{2.5}$ inhalation in Seoul metropolitan city.

The Seoul metropolitan area is composed of many satellite cities, which have high population and vehicle densities. However, there are few studies of the health effects on air pollution conducted in satellite cities of the Seoul Metropolitan area. For this reason, 
we investigated the health effects of air pollution in Suwon city, one of the highly populated satellite cities of Seoul.

The Air Quality Health Impact Assessment Tool (AirQ) software was developed by the WHO European Centre for Environment Health, Bilthoven Division. The AirQ is specialized software that enables the user to assess the potential impact on human health of exposure to a given air pollution in a defined urban area during a certain time period, and has been applied in some recent studies (e.g. Naddafl et al., 2012; Fattore et al., 2011). According to the Health and Air Pollution in Asia (PAPA) study, although the social and environmental conditions may be quite different, it is reasonable to apply estimates derived from the previous health effect of air pollution studies in the West, to Asia in public (Wong et al., 2008). So, in order to estimate the health effects of air pollution in Suwon city, AirQ software was used in this study.

\section{MATERIALS AND METHODS}

\section{1 Site Characterization and Air pollution Data}

Suwon city is located about $40 \mathrm{~km}$ from the south of Seoul, and has a total area of about $121 \mathrm{~km}^{2}$ (i.e. about $12 \mathrm{~km} \times 12 \mathrm{~km}$ ). Within the Metropolitan regions of Seoul, Suwon city presents the highest population, of about 1.18 million people, with about 9,589 hab $\mathrm{km}^{-2}$ of population density in 2011. From 1981 to 2010 , the annual average temperature was around $12^{\circ} \mathrm{C}$ (with minima of about $7.5^{\circ} \mathrm{C}$ and maxima of about 17.2 ${ }^{\circ} \mathrm{C}$ ) and the difference between warmer and colder months was around $28.5^{\circ} \mathrm{C}$. The climate is considered continental climate with cold. Annual air humidity is about $69 \%$ with insignificant variations during the year, and the total annual precipitation is about $1312 \mathrm{~mm}$, with more intensity in summer months. The prevailing wind is WNW during almost all of the year, and the mean wind velocity is around $1.7 \mathrm{~m} \mathrm{~s}^{-1}$ (Korea Meteorological Administration, 2011).

The Korean Ministry of Environment (MOE) sets National Ambient Air quality Standards (NAAQS) for seven common "criteria" pollutants $\left(\mathrm{PM}_{10}, \mathrm{O}_{3}, \mathrm{~Pb}, \mathrm{CO}\right.$, $\mathrm{NO}_{2}$, Benzene and $\mathrm{SO}_{2}$ ) at levels adequate to protect public health and the environment. A national network of air quality monitors measures the ambient levels of each pollutant, to determine if a community meets each of the seven NAAQS. Observations from this national network are also used to characterize trends in the daily and annual changes of these pollutants.

Suwon city has six fixed-site monitoring sites, which are controlled by the National Monitoring Network.

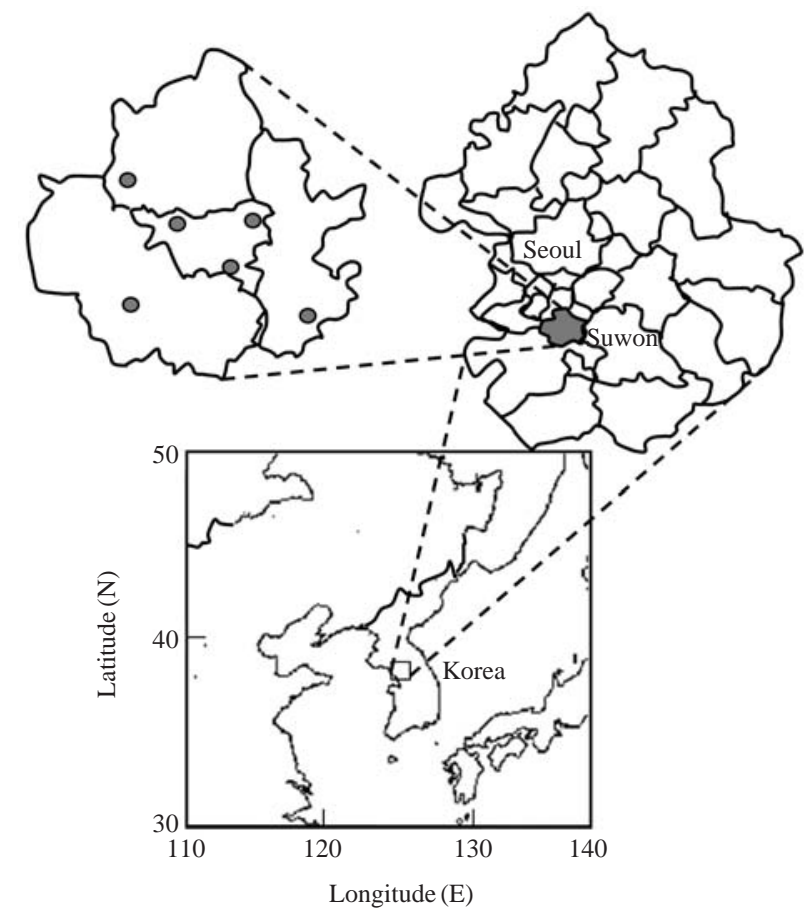

Fig. 1. Location of Suwon city (circles reveal fixed sampling positions of Suwon city).

The locations of the sampling sites in Suwon city are shown in Fig. 1. In this study, hourly air pollution data between January and December 2011 were obtained from six fixed monitoring sites, and used to evaluate the health effects on air pollution.

\section{2 AirQ Software}

The Air Quality Health Impact Assessment Tool (AirQ) was developed by the WHO European Centre for Environment Health, Bilthoven Division, and proposed by the World Health Organization. The AirQ is specialized software that enables the user to assess the potential impact on human health of exposure to a given air pollutant in a defined urban area, during a certain time period. The assessment is based on the attributable proportion (AP), defined as the fraction of the health outcome in a certain population attributable to exposure to given atmospheric pollutant, assuming a proven causal relation between exposure and health outcome, and no major confounding effects in that association. According to the WHO (2006), the AP can be easily calculated by the following general formula:

$$
\mathrm{AP}=\sum\left\{[\mathrm{RR}(\mathrm{c})-1] \times \frac{\mathrm{p}(\mathrm{c})}{\sum[\mathrm{RR}(\mathrm{c}) \times \mathrm{p}(\mathrm{c})]}\right.
$$

Where, AP is the attributable proportion of the health 
Table 1. Relative risk (RR) with $95 \%$ confidence intervals (95\% CI), and corresponding reference, implemented in AirQ 2.2 .3 software and used for the health effect estimates in this study.

\begin{tabular}{|c|c|c|c|c|c|c|}
\hline \multirow[b]{2}{*}{ Outcome } & \multirow[b]{2}{*}{$\begin{array}{c}\text { Health } \\
\text { endpoint }\end{array}$} & \multirow[b]{2}{*}{ Incidence $^{a}$} & \multicolumn{4}{|c|}{ Relative Risk $(95 \% \mathrm{CI})$ per $10 \mu \mathrm{g} / \mathrm{m}^{3}$} \\
\hline & & & $\begin{array}{c}\mathrm{PM}_{10} \\
\text { (Daily average) }\end{array}$ & $\begin{array}{c}\mathrm{O}_{3} \\
(8 \mathrm{hr} \text { average })\end{array}$ & $\begin{array}{c}\mathrm{NO}_{2} \\
(1 \mathrm{hr} \text { average })\end{array}$ & $\begin{array}{c}\mathrm{SO}_{2} \\
\text { (Daily average) }\end{array}$ \\
\hline \multirow[t]{3}{*}{ Mortality } & $\begin{array}{c}\text { Total ICM-9-CM } \\
<800\end{array}$ & 380.5 & $\begin{array}{c}1.006 \\
(1.004-1.008) \\
\text { (Anderson et al., } \\
\text { 2004) }\end{array}$ & $\begin{array}{c}1.003 \\
(1.002-1.005) \\
\text { (Gryparis et al., } \\
2004)\end{array}$ & $\begin{array}{c}1.003 \\
(1.002-1.004) \\
(\text { Samoli et al. } \\
\text { 2006) }\end{array}$ & $\begin{array}{c}1.004 \\
(1.003-1.0048) \\
(\mathrm{WHO}, 1999)\end{array}$ \\
\hline & $\begin{array}{c}\text { Cardiovascular } \\
\text { ICM-9-CM } 390 \\
-459\end{array}$ & 84.5 & $\begin{array}{c}1.009 \\
(1.005-1.013) \\
\text { (Anderson et al., } \\
2004)\end{array}$ & $\begin{array}{c}1.005 \\
(1.002-1.007) \\
\text { (Gryparis et al., } \\
2004)\end{array}$ & $\begin{array}{c}1.004 \\
(1.003-1.005) \\
\text { (Samoli et al., } \\
2006)\end{array}$ & $\begin{array}{c}1.008 \\
(1.002-1.012) \\
\text { (Burret \& Doles, } \\
1997)\end{array}$ \\
\hline & $\begin{array}{c}\text { Respiratory } \\
\text { ICM-9-CM } 460 \\
-519\end{array}$ & 28.8 & $\begin{array}{c}1.013 \\
(1.005-1.02) \\
\text { (Anderson et al., } \\
\text { 2004) }\end{array}$ & $\begin{array}{c}1.013 \\
(1.007-1.015) \\
\text { (Gryparis et al., } \\
2004)\end{array}$ & & $\begin{array}{c}1.01 \\
(1.006-1.014) \\
\text { (Burret \& Doles, } \\
1997)\end{array}$ \\
\hline \multirow[t]{4}{*}{ Morbidity } & $\begin{array}{c}\mathrm{HA}^{\mathrm{e}} \\
\text { Respiratory } \\
\text { Disease }\end{array}$ & 1260 & $\begin{array}{c}1.008 \\
(1.0048-1.0112) \\
(\mathrm{WHO}, 2000)\end{array}$ & & & \\
\hline & $\begin{array}{c}\text { HA } \\
\text { Cardiovascular } \\
\text { Disease }\end{array}$ & 436 & $\begin{array}{c}1.009 \\
(1.006-1.013) \\
\text { (Touloumi et al., } \\
1996)\end{array}$ & & & \\
\hline & $\begin{array}{c}\mathrm{HA} \\
\mathrm{COPD}^{\mathrm{d}}\end{array}$ & 101.4 & & $\begin{array}{c}1.0086 \\
(1.0044-1.013) \\
(\text { Spix }, 1997)\end{array}$ & $\begin{array}{c}1.0026 \\
(1.0006-1.0044) \\
\text { (Samoli et al. } \\
\text { 2006) }\end{array}$ & $\begin{array}{c}1.044 \\
(1.0-1.011) \\
(\text { Spix, 1997) }\end{array}$ \\
\hline & $\begin{array}{c}\text { Acute } \\
\text { myocardial } \\
\text { infraction }\end{array}$ & 132 & & & $\begin{array}{c}1.0036^{\mathrm{c}} \\
(1.0015-1.0084) \\
\text { (Anderson \& Leon, } \\
1996)\end{array}$ & $\begin{array}{c}1.0064 \\
(1.0026-1.0101) \\
\text { (Anderson \& Leon, } \\
1996)\end{array}$ \\
\hline
\end{tabular}

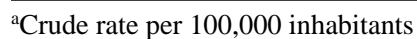

'International Classification of Diseases, 9th Revision, Clinical Modification (ICD-9-CM).

'Daily average

${ }^{\mathrm{d} C h r o n i c}$ obstructive pulmonary disease

${ }^{\text {e}}$ Hospital Admission

outcome, RR is the relative risk for a given health outcome, in category "c" of exposure, obtained from the exposure-response functions derived from epidemiological studies, and $\mathrm{p}(\mathrm{c})$ is the proportion of the population in category "c" of exposure. If the baseline frequency of the health outcome in the population under investigation is known, the rate attributable to the exposure can be calculated as

$$
\mathrm{IE}=\mathrm{I} \times \mathrm{AP}
$$

Where, IE is the rate of the health outcome attributable to the exposure, and I is the baseline frequency of the health outcome in the population under investigation. Finally, knowing the size of the population, the number of cases attributable to the exposure can be estimated as follows:

$$
\mathrm{NE}=\mathrm{IE} \times \mathrm{N}
$$

Where, NE is the number of cases attributed to the exposure and $\mathrm{N}$ is the size of the population investigated.

RR gives the increase in probability of adverse effect associated with a given change in the exposure levels, and comes from time-series studies, where day-today changes in air pollutants over long periods were related to daily mortality, hospital admissions and other public health indicators (Fattore et al., 2011).

RR values used in this study are shown in Table 1, and are based on the default WHO values in AirQ software. The RR values used for $\mathrm{PM}_{10}$ were summary estimates derived from a quantitative meta-analysis of peer-reviewed studies that focused on European in- 
Table 2. Summary of concentrations of air pollutants, Suwon city (2011).

\begin{tabular}{|c|c|c|c|c|c|}
\hline Pollutant & Average & Maximum & Minimum & $98 \%$ & No. of data \\
\hline $\mathrm{PM}_{10}$, Annual $24 \mathrm{hr}\left(\mu \mathrm{g} / \mathrm{m}^{3}\right)$ & 52 & 278 & 5 & 149 & 365 \\
\hline $\mathrm{O}_{3}$, Annual $8 \mathrm{hr}\left(\mu \mathrm{g} / \mathrm{m}^{3}\right)$ & 43 & 191 & 2 & 120 & 1096 \\
\hline $\mathrm{NO}_{2}$, Annual $24 \mathrm{hr}\left(\mu \mathrm{g} / \mathrm{m}^{3}\right)$ & 75 & 169 & 12 & 146 & 365 \\
\hline $\mathrm{SO}_{2}$, Annual $24 \mathrm{hr}\left(\mu \mathrm{g} / \mathrm{m}^{3}\right)$ & 15 & 44 & 3 & 32 & 365 \\
\hline
\end{tabular}

vestigations (Anderson et al., 2004). For $\mathrm{O}_{3}, \mathrm{SO}_{2}$ and $\mathrm{NO}_{2}$, the RR values came directly from published studies on short-term effects within the APHEA project (Samoli et al., 2006; Gryparis et al., 2004). The baseline rates of the health outcomes were based on statistics available on-line from Statistic Korea (http:// kostat.go.kr).

\subsection{Exposure Assessment}

Air concentrations of $\mathrm{PM}_{10}, \mathrm{O}_{3}, \mathrm{NO}_{2}$, and $\mathrm{SO}_{2}$ were measured by six fixed-site monitoring sites, which are controlled by the National Monitoring Network in Suwon city. In this study, air pollutants data from January 2011 to December 2011 from the six stations were used. Exposure was estimated considering the city of Suwon as single agglomerate, with a residential population of 1,118,000 people.

For all the pollutants, the parameters required by the AirQ software (annual and seasonal maximum and annual $98^{\text {th }}$ percentiles) were obtained, and concentrations were divided into $10 \mu \mathrm{g} / \mathrm{m}^{3}$ categories, corresponding to equivalent exposure categories. For $\mathrm{O}_{3}$, data were expressed as a $1 \mathrm{~h}$ average, and an $8 \mathrm{~h}$ moving average. For $\mathrm{NO}_{2}$, data were expressed as both $1 \mathrm{~h}$ and daily average concentrations, and $\mathrm{PM}_{10}$ and $\mathrm{SO}_{2}$ as daily averages.

The software assumes that measured concentrations are representative of the average exposure of the people. For example, if $5 \%$ of sampling day concentrations were between 10 and $20 \mu \mathrm{g} / \mathrm{m}^{3}$, it was assumed that people were exposed to the corresponding concentration for 5\% of their time (Fattore et al., 2011).

\section{RESULTS AND DISCUSSION}

Table 2 shows a summary of the statistics of pollutant data in Suwon city. The highest $\mathrm{PM}_{10}$ concentration was detected in the winter period, with a maximum value of $278 \mu \mathrm{g} / \mathrm{m}^{3}$. The obtained results reveal that the daily average of $\mathrm{PM}_{10}$ in Suwon city was similar to the guideline values prescribed by the air quality guideline $\left(50 \mu \mathrm{g} / \mathrm{m}^{3}\right)$ of $\mathrm{WHO}(2006)$. For $\mathrm{O}_{3}$, the maximum $8 \mathrm{~h}$ average concentration was $191 \mu \mathrm{g} / \mathrm{m}^{3}$, detected as expected in summer; this value was 1.9 times larger than the guideline value of WHO prescribed by the daily maximum 8-hour mean $100 \mu \mathrm{g} / \mathrm{m}^{3}$ (WHO, 2006). The daily average $\mathrm{NO}_{2}$ and $\mathrm{SO}_{2}$ concentrations, respectively, were 75 (this value is larger than the WHO guideline of $40 \mu \mathrm{g} / \mathrm{m}^{3}$ ) and $15 \mu \mathrm{g} / \mathrm{m}^{3}$ (this value is smaller than the WHO guideline of $20 \mu \mathrm{g} / \mathrm{m}^{3}$ ) were detected in the winter period.

Fig. 2 (a)-(d) illustrate the concentrations of various pollutants intervals, and the percentage of days in which people were exposed to these concentrations. These data were used to estimate the short-term effects.

The short-term health impacts of exposure to $\mathrm{PM}_{10}$, $\mathrm{O}_{3}, \mathrm{NO}_{2}$ and $\mathrm{SO}_{2}$ above a reference value of $10 \mu \mathrm{g} / \mathrm{m}^{3}$ are shown in Tables $3\left(\mathrm{PM}_{10}\right.$ and $\left.\mathrm{O}_{3}\right)$, and $4\left(\mathrm{NO}_{2}\right.$ and $\mathrm{SO}_{2}$ ). These impacts were estimated as the increase in all causes of cardiovascular and respiratory mortality for short-term exposure. For $\mathrm{O}_{3}$, the numbers of excess cases over total mortality, cardiovascular and respiratory mortality (Table 3 ) were based on the RR values from the APHEA-2 project (Samoli et al., 2006), which investigated the health effects of ambient $\mathrm{O}_{3}$ in 23 European cities/areas for at least three years (Gryparis et al., 2004). For $\mathrm{NO}_{2}$, the estimated short-term effects (Table 4) are based on the pooled estimates for the increase in mortality associated with an increase of 10 $\mu \mathrm{g} / \mathrm{m}^{3}$ in 30 European cities participating in the APHEA-2 project (Samoli et al., 2006).

In this study, $\mathrm{PM}_{10}$ had the greatest health impact on the 1,118,000 inhabitants of Suwon city, causing an excess of total mortality of 105.5 out of 4,254 people in a year. Recently, the AirQ software has been used by other investigators to assess the human health impact of $\mathrm{PM}_{10}$ (Naddafl et al., 2012; Fattore et al., 2011). Fattore et al. (2011) estimated the human health risk in relation to air quality in two municipalities in an industrialized area of Northern Italy, where the authors found that $\mathrm{PM}_{10}$ had a health impact on the 24,000 inhabitants of the two small towns, causing an excess of total mortality of 4.4 out of 177 in a year. Naddafl et al. (2012) provided a quantification of the short-term health effect of air pollutants for people living in Tehran, by using the WHO approach. They suggested $\mathrm{PM}_{10}$ had the greatest health impact on the 8,700,000 inhabitants of Tehran city, causing an excess of total mortality of 2,194 out of 47, 284 people in a year. These other results, if normalized to the population in Suwon city $(1,118,000$ inhabitants), would be shown to be 


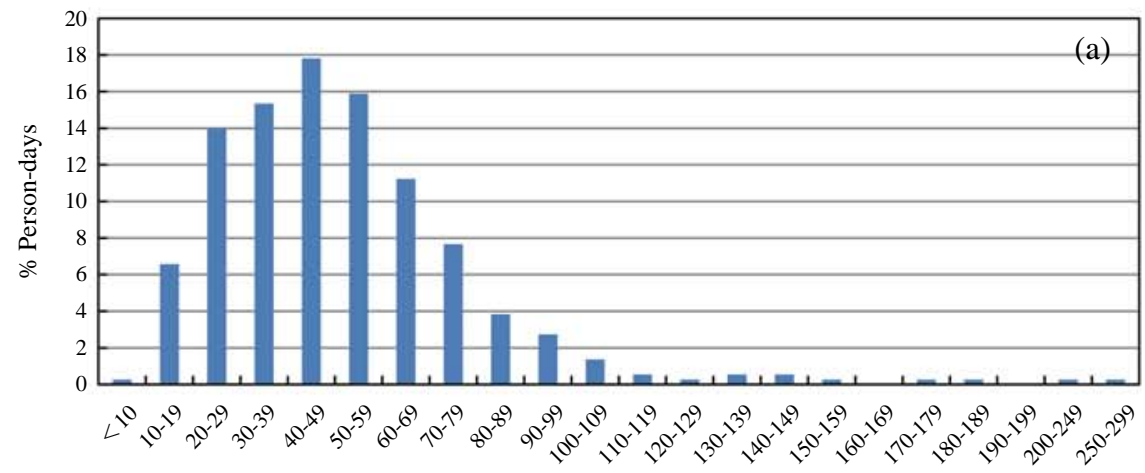

Concentration intervas for $\mathrm{PM}_{10}\left(\mu \mathrm{g} / \mathrm{m}^{3}\right)$

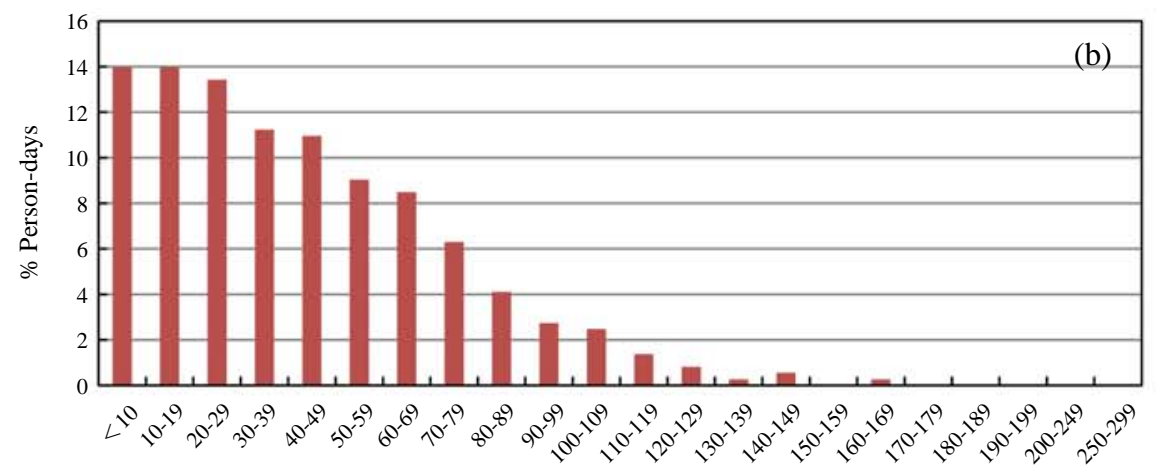

Concentration intervas for $\mathrm{O}_{3}\left(\mu \mathrm{g} / \mathrm{m}^{3}\right)$
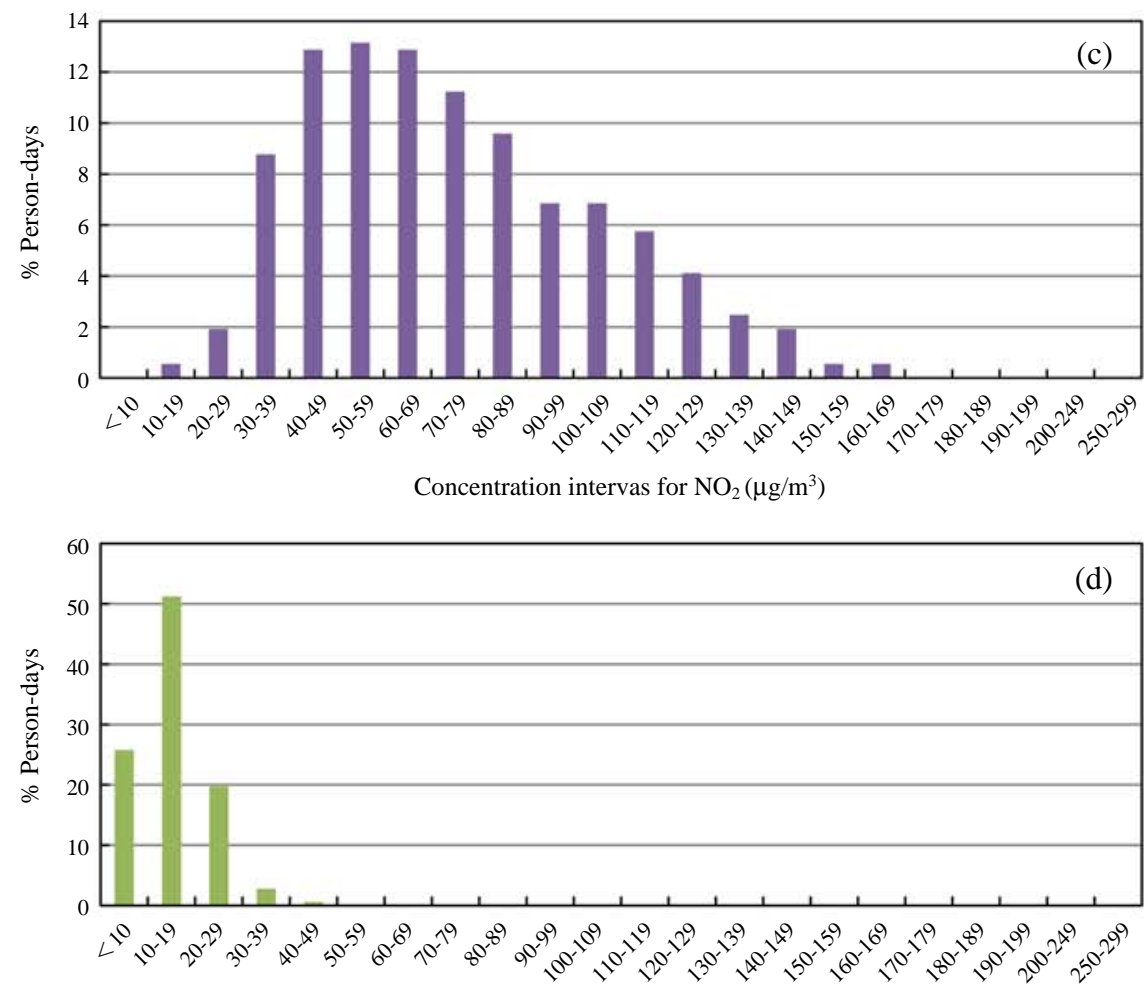

Concentration intervas for $\mathrm{SO}_{2}\left(\mu \mathrm{g} / \mathrm{m}^{3}\right)$

Fig. 2. Percentage of days on which people in Suwon city are exposed to different concentrations of (a) $\mathrm{PM}_{10}$, (b) $\mathrm{O}_{3}$, (c) $\mathrm{NO}_{2}$, (d) $\mathrm{SO}_{2}$. 
Table 3. Estimated attributable proportion (AP) expressed as percentage and number of excess cases in a year due to short-term exposure above $10 \mu \mathrm{g} / \mathrm{m}^{3}$ for $\mathrm{PM}_{10}$ and $\mathrm{O}_{3}$.

\begin{tabular}{lcccc}
\hline \multicolumn{1}{c}{ Air pollution } & \multicolumn{2}{c}{$\mathrm{PM}_{10}$} & $\mathrm{O}_{3}$ \\
\hline \multicolumn{1}{c}{ Health end points } & $\begin{array}{c}\text { Attributable proportion } \\
\text { (uncertainty range) }\end{array}$ & $\begin{array}{c}\text { No. of excess case } \\
\text { (uncertainty range) }\end{array}$ & $\begin{array}{c}\text { Attributable proportion } \\
\text { (uncertainty range) }\end{array}$ & $\begin{array}{c}\text { No. of excess case } \\
\text { (uncertainty range) }\end{array}$ \\
\hline Total mortality & $2.5(1.67-3.28)$ & $105.5(70.9-139.5)$ & $1.0(0.67-1.66)$ & $42.7(28.6-70.8)$ \\
Cardiovascular mortality & $3.7(2.06-5.22)$ & $34.7(19.6-49.3)$ & $1.7(0.67-2.31)$ & $15.7(6.3-21.9)$ \\
Respiratory mortality & $5.2(2.06-7.81)$ & $16.8(6.7-25.2)$ & $4.2(2.31-4.83)$ & $13.6(7.4-15.6)$ \\
HA Res. Disease & $3.3(1.99-4.53)$ & $462.0(280.9-634.8)$ & & $32.1(16.6-47.8)$ \\
HA Car. Disease & $3.7(2.48-5.22)$ & $179.1(120.9-254.6)$ & & \\
HA COPD & & & $2.3(1.47-4.21)$ & \\
Acute Myocardial infraction & & & & \\
\hline
\end{tabular}

Table 4. Estimated attributable proportion (AP) expressed as percentage and number of excess cases in a year due to short-term exposure above $10 \mu \mathrm{g} / \mathrm{m}^{3}$ for $\mathrm{NO}_{2}$ and $\mathrm{SO}_{2}$.

\begin{tabular}{lcccc}
\hline \multicolumn{1}{c}{ Air pollution } & \multicolumn{2}{c}{$\mathrm{NO}_{2}$} & $\mathrm{SO}_{2}$ \\
\multicolumn{1}{c}{ Health end points } & $\begin{array}{c}\text { Attributable proportion } \\
\text { (uncertainty range) }\end{array}$ & $\begin{array}{c}\text { No. of excess case } \\
\text { (uncertainty range) }\end{array}$ & $\begin{array}{c}\text { Attributable proportion } \\
\text { (uncertainty range) }\end{array}$ & $\begin{array}{c}\text { No. of excess case } \\
\text { (uncertainty range) }\end{array}$ \\
\hline Total mortality & $1.9(1.28-2.53)$ & $81.3(54.5-107.7)$ & $0.3(0.19-0.31)$ & $10.9(8.1-13.0)$ \\
Cardiovascular mortality & $2.5(1.91-3.14)$ & $23.9(18.0-29.7)$ & $0.5(0.13-0.76)$ & $4.8(1.2-7.2)$ \\
Respiratory mortality & & & $0.6(0.38-0.89)$ & $2.0(1.2-2.9)$ \\
HA Res. Disease & & & & \\
HA Car. Disease & $1.75(0.39-2.78)$ & $18.8(4.4-31.5)$ & $2.8(1.48-4.21)$ & $32.1(16.6-47.8)$ \\
HA COPD & $2.3(0.96-5.17)$ & $33.7(14.2-76.3)$ & $0.4(0.17-0.62)$ & $6.0(2.5-9.5)$ \\
Acute Myocardial infraction & &
\end{tabular}

1.7-1.8 times higher than those reported for $\mathrm{PM}_{10}$ in this study (Table 3 ). As other studies did, $\mathrm{PM}_{10}$ is the pollutant with the biggest health effects in the present study.

The effect of $\mathrm{O}_{3}$ and $\mathrm{NO}_{2}$ on total mortality was an excess of about 42.7 , and 81.3 cases, respectively, in a year in Suwon city (about 1,180,000 inhabitants). In the Italian study, $\mathrm{O}_{3}$ and $\mathrm{NO}_{2}$ caused about 2.6 and 3.1 excess cases of total mortality (about 24,000 inhabitants), respectively; and the Tehran study (of about $8,700,000$ inhabitants) showed 819 and 1,050 excess cases of total mortality for $\mathrm{O}_{3}$, and $\mathrm{NO}_{2}$, respectively. The $\mathrm{O}_{3}$ impact on human health of Suwon city, if normalized to Suwon city, would result in about 0.67 and 0.59 times lower mortality than the two municipalities in industrialized northern Italy and Tehran, respectively. For $\mathrm{NO}_{2}$, Suwon city was very similar to those reported in the northern Italian and Tehran study.

Although the results of this study are in line with those of other studies that apply AirQ software, this study has some limitations. One of the limitations of this study is that the health impact focuses on individual air pollutants, without considering the simultaneous exposure to several compounds, which is what actually occurs. The second limitation is that this study assumes that concentrations measured in fixed sampling points are representative of the average ex- posure suffered by people living in Suwon city. A further limitation is due to the RR estimates derived in studies of different populations, in comparison to the one under investigation. In particular, for $\mathrm{PM}_{10}, \mathrm{O}_{3}$, $\mathrm{NO}_{2}$ and $\mathrm{SO}_{2}$, the RRs were mainly based on studies on the European population.

\section{CONCLUSIONS}

This study illustrates a study case using the WHO approach to assess the impact of atmospheric pollution on human health for people living in Suwon city. The AirQ software and the approach proposed by the WHO provide quantitative data on the impact of $\mathrm{PM}_{10}$, $\mathrm{SO}_{2}, \mathrm{NO}_{2}$ and $\mathrm{O}_{3}$ on the health of people living in a certain area.

In spite of some limitations, the results of this study are generally consistent with those of other health impact studies that used AirQ software. Therefore, the results of this study are comparable to other city studies. Even though the magnitude of the health impact estimated for the city of Suwon is lower than for the two municipalities in an industrialized area of Northern Italy, and the capital city of Iran, the impact of air pollution on human health for people living in Suwon city reveals considerable amount in this study, there 
still remains the need for action to reduce the health burden of air pollution.

\section{REFERENCES}

Anderson, H.R., Atkinson, R.W., Peacock, J.L., Marston, L., Konstantinou, K. (2004) Meta-Analysis of Time Series Studies of Particulate Matter (PM) and Ozone $\left(\mathrm{O}_{3}\right)$. WHO Europe Report of a WHO task group (EUR/ 04/5042688), pp. 13-25.

Anderson, H.R., Leon, A.P. (1996) Air pollution and daily mortality in London: 1987-92. BMJ 312, 665-669.

Atkinson, R.W., Cohen, A., Mehta, S. (2012) Anderson HR. Systematic review and meta-analysis of epidemiological time-series studies on outdoor air pollution and health in Asia. Air Quality, Atmosphere \& Health 5(4), 383-391.

Bae, H.J., Park, J.I. (2009) Health benefits of improving air quality in the rapidly aging Korean society. Science of the Total Environment 407(23), 5971-5977.

Burret, R.T., Doles, R.E. (1997) Association between Ambient Carbon Monoxide Levels and Hospitalization for Congestive Heart Failure in the Elderly in 10 Canadian cities. Epidemiology 8(2), 162-167.

Fattore, E., Paiano, V., Borgini, A., Tittarelli, A., Bertoldi, M., Crosignani, P., Fanelli, R. (2011) Human health risk in relation to air quality in two municipalities in an industrialized area of northern Italy. Environmental Research 111(8), 1321-1327.

Gryparis, A., Forsberg, B., Katsouyanni, K., Analitis, A., Touloumi, G., Schwartz, J., Samoli, E., Medina, S., Anderson, H.R., Niciu, E.M., Wichmann, H.E., Kriz, B., Kosnik, M., Skorkovsky, J., Vonk, J.M., Dortbudak, Z. (2004) Acute effects of ozone on mortality from the "air pollution and health: a European approach" project. American Journal of Respiratory and Critical Care Medicine 170(10), 1080-1087.

HEI (2010) HEI panel on the health effects of traffic-related air pollution: Traffic related-air pollution: a critical review of the literature on emissions, exposure and health effects, Special report. 17, Boston, MA: Health Effects Institute, pp. 1-386.

Kim, S.Y., Lee, J.T., Hong, Y.C., Ahn, K.J., Kim, H. (2004) Determining the threshold effect of ozone on daily mortality: an analysis of ozone and mortality in Seoul, Korea, 1995-1999. Environmental Research 94(2), 113-119.

Korea Meteorological Administration (2011) Climatological Normals of Korea 1981-2010. Seoul, Republic of Korea.

Lee, J.T., Son, J.Y., Cho, Y.S. (2007) The adverse effects of fine particle air pollution on respiratory function in the elderly. Science of the Total Environment 385(1-3), 28-36.

Lee, Y.J., Lim, Y.W., Yang, J.Y., Kim, C.S., Shin, Y.C., Shin, D.C. (2011) Evaluating the PM damage cost due to urban air pollution and vehicle emissions in Seoul,
Korea, Journal of Environmental Management 92(3), 603-609.

Naddafi, K., Hassanvand, M.S., Yunesian, M., Momeniha, F., Nabizadeh, R., Faridi, S., Gholampour, A. (2012) Health impact assessment of air pollution in megacity of Tehran, Iran. Iranian Journal of Environmental Health Sciences \& Engineering 9, 1-7.

Pacel, M., Corso, M., Chanel, O., Declercq, C., Badaloni, C., Cesaroni, G., Henschel, S., Meister, K., Haluza, D., Martin-Olmedo, P., Medina, S. and on behalf of the Aphekom group (2013) Assessing the public health impacts of urban air pollution in 25 European cities: Results of the Aphekom project. Science of the Total Environment 449, 390-400.

Pope, C.A., Dockery, D.W. (2006) Health effects of fine particulate air pollution: lines that connect. Journal of Air Waste Management Association 56(6), 709-742.

Samoli, E., Aga, E., Touloumi, G., Nisiotis, K., Forsberg, B., Lefranc, A., Pekkanen, J., Wojtyniak, B., Schindler, C., Niciu, E., Brunstein, R., Dodic Fikfak, M., Schwartz, J., Katsouyanni, K. (2006) Short-term effects of nitrogen dioxide on mortality: an analysis within the APHEA project. European Respiratory Journal 27(6), 1129-1138.

Spix, C. (1997) Short-Term Effects of Air Pollution on Hospital Admissions of Respiratory Diseases in Europe: A Quantitative Summary of APHEA Study Results. Archives of Environmental Health: An International Journal 53(1), 54-64.

Touloumi, G., Samoli, E., Katsouyanni, K. (1996) Daily mortality in "winter type" air pollution in Athens - a time-series analysis within the APHEA project. Journal of Epidemiology\& Community Health 50 (suppl 1), S47-S51.

WHO (1999) Monitoring Ambient Air Quality for Health Impact Assessment. WHO Regional Publications; European Series, NO 85.

WHO (2000) Air Quality Guidelines for Europe II. 2nd Edition, WHO Regional Publications; European Series, NO. 91.

WHO (2006) WHO Air quality guidelines for particulate matter, ozone, nitrogen dioxide and sulfur dioxide: Summary of risk assessment, Global update 2005. World Health Organization, Available at: http://www.euro. who.int/Document/E87950.pdf.

Wong, C.M., Nuntavaran, V.V., Kan, H., Qian, Z. (2008) Public Health and Air Pollution in Asia (PAPA): A multicity study of short-term effects of air pollution on mortality. Environmental Health Perspectives 116(9), 1195-1202.

Yi, O.H., Hong, Y.C., Kim, H. (2010) Seasonal effect of PM10 concentrations on mortality and morbidity in Seoul, Korea: A temperature-matched case-crossover analysis. Environmental Research 110(1), 89-95.

(Received 27 September 2013, revised 26 November 2013, accepted 4 December 2013) 